\title{
HANDBUCH
}

FÜR DIE

\section{DEUTSCHE HANIDELSMARINE}

\author{
AUF DAS JAHR
}

1930

HERAUSGEGEBEN

VOM

REICHSVERKEHRSMINISTERIUM

BERLIN

VERLAG ION WALTER DE GRUYTER \& CO. 
